\title{
KEPEMIMPINAN KEPALA SEKOLAH DALAM PELAKSANAAN PROGRAM PENGEMBANGAN DAN PENINGKATAN SENI TRADISIONAL JENJANG SD, SMP, DAN SMA DI PROVINSI JAWA TIMUR
}

\author{
Oleh: \\ Subianto Karoso'), Syunu Trihantoyo' ${ }^{2)}$ \\ ${ }^{1}$ Pendidikan Seni, Drama, dan Musik FBS Unesa \\ 2Manajemen Pendidikan FIP Unesa \\ 1subiantokaroso@unesa.ac.id
}

\begin{abstract}
Abstrak
Kegiatan pengabdian masyarakat ini didasarkan pada upaya dari Pemerintah Provinsi Jawa Timur dalam rangka melestarikan seni tradisional dari kepunahan dengan memperkenalkan seni tradisional untuk siswa melalui studio seni tari di sekolah-sekolah di Jawa Timur. Pendirian program Pengembangan dan Peningkatan Seni Tradisonal (PPST) untuk menyediakan media belajar dan penghargaan bagi siswa dalam seni tari tradisional. Tujuan dalam penulisan artikel ini adalah untuk mengetahui model kepemimpinan kepala sekolah dalam PPST jenjang Sekolah Dasar, SMP, dan SMA di Jawa Timur serta konsep kepemimpinan transformasional Ki Hajar Dewantara dalam memenuhi program pengembangan dan peningkatan seni tradisional di Jawa Timur. Metode yang dilakukan dengan menggunakan pendekatan kualitatif. Teknik pengumpulan data dilakukan dengan metode wawancara, observasi, dan dokumentasi yang dilaksanakan dengan memberikan materi pelatihan tentang pengembangan dan peningkatan seni tari tradisional. Hasil dari kegiatan ini, terdapat peran strategis kepala sekolah dalam mengembangkan dan melestarikan seni tari tradisional dilihat dari bentuk kepemimpinan transformasional dan kepemimpinan pendidikan Ki Hadjar Dewantara.
\end{abstract}

Kata Kunci: kepemimpinan pendidikan, seni tari, Pengembangan dan Peningkatan Seni Tradisonal (PPST)

\begin{abstract}
Community service activities are based on the efforts of the Provincial Government of East Java to preserve the traditional art of extinction by introducing traditional art studio for students through the art of dance in schools in East Java. Establishment of Development and Improvement program Traditional Arts (PPST) to provide a medium of learning and appreciation for students in traditional dance. The purpose in writing this article is to determine the model of school leadership in PPST elementary school level, junior and senior high schools in East Java as well as the concept of transformational leadership Ki Hajar Dewantara in meeting program development and improvement of traditional art in East Java. The method is performed using a qualitative approach. Data collected by interview, observation, and documentation carried out by providing training materials on the development and improvement of traditional dance. The results of these activities, there is the strategic role of the principal in developing and preserving the art of traditional dance of the shape of transformational leadership and educational leadership Ki Hadjar Dewantara.
\end{abstract}

Keywords: educational leadership, dance, Pengembangan dan Peningkatan Seni Tradisonal (PPST)

\section{PENDAHULUAN}

Tujuan pendidikan nasional adalah mencerdaskan kehidupan bangsa dan mengembangkan manusia Indonesia seluruhnya, yaitu manusia yang beriman dan bertaqwa kepada Tuhan Yang Maha Esa dan berbudi pekerti luhur, pengetahuan dan keterampilan, kesehatan jasmani dan rohani, kepribadian yang mantap dan mandiri (Undang-Undang Republik Indonesia Nomor 20 Tahun 2003 Tentang Sistem Pendidikan Nasional). Guru sebagai bagian terpenting dalam proses pembelajaran dituntut untuk memenuhi sejumlah persyaratan, diantaranya pendidikan yang professional dan berkualitas, memiliki kompetensi dalam karya ilmiah, memiliki kemampuan komunikasi yang baik dengan siswa, memiliki semangat kreatif dan produktif, memiliki etos kerja, dan komitmen untuk profesinya.

Jawa Timur sebagai salah satu provinsi di Indonesia yang memiliki keragaman seni dan budaya. Dalam perspektif pendidikan, seni dipandang sebagai salah satu alat atau media untuk memberikan keseimbangan antara intelektualitas dan kepekaan, rasionalitas dan irasionalitas, dan pikiran dan 
kepekaan emosional. Keragaman seni tradisi yang ditemukan di Jawa Timur perlu terus dilestarikan dari kepunahan. Salah satu upaya nyata yang telah dilaksanakan oleh Pemerintah Provinsi Jawa Timur dalam rangka melestarikan seni tradisional adalah untuk memperkenalkan seni tradisional untuk siswa melalui studio kesenian tradisional di sekolah dengan pembentukan Pengembangan dan Peningkatan Seni Tradisional (PPST).

Itulah sebabnya tujuan yang ingin dicapai oleh PPST adalah untuk membangun, mengembangkan, dan melestarikan kekayaan seni dan budaya sebagai penyangga budaya nasional. Program PPST juga berfungsi untuk mengembangkan daya kreatif dan kreativitas siswa, khususnya di bidang seni tradisional. Mengangkat harkat dan martabat seni dan budaya serta dalam kehidupan budaya dan sosial. Juga menyediakan lembaga bimbingan dan apresiasi kepada siswa dalam bidang seni tari, terutama latihan kesenian tradisional.

PPST di sekolah adalah program pendidikan dan pengembangan kesenian sekolah di Unit Pelaksana Teknis Daerah (UPTD) Dinas Pendidikan Provinsi Jawa Timur untuk memberikan wadah dalam mengekspresikan dan mengapresiasi siswa dalam seni tari, khususnya seni tradisional. Selain itu, melalui PPST di sekolah diharapkan dapat membentuk dasar yang kuat dalam rangka upaya untuk melestarikan dan mengembangkan seni dan budaya di Jawa Timur.

Sejak pertama kali diluncurkan pada tahun 2002 hingga saat ini, PPST awalnya dikenal sebagai Asosiasi Penggemar Seni Tradisional yang telah berkembang hampir di seluruh Jawa Timur. Keberadaan PPST diharapkan tidak hanya untuk berlatih seni tradisional, dipentaskan di apresiasi dalam forum atau perayaan lainnya, tetapi harus dapat memiliki dampak positif pada keberadaan kesenian tradisional lokal yang tumbuh di masyarakat.

Dalam mewujudkan pelestarian seni tradisional, diperlukan seorang pemimpin program PPST atau mentor yang berkomitmen untuk mengembangkan organisasi, dalam hal ini kepala sekolah. Kepemimpinan pendidikan Ki Hajar Dewantara sebagai salah satu tokoh pendidikan nasional telah merumuskan bahwa pokok sebagai pemimpin di lembaga pendidikan harus mampu menjadi contoh, pendorong semangat, dan memberikan dukungan moral bagi guru dan siswa yang dipimpin.

\section{METODE PELAKSANAAN}

Pendekatan yang digunakan dalam penelitian ini, menurut jenis datanya adalah pendekatan kualitatif. Bogdan and Biklen (1997) mendefinisikan penelitian kualitatif "...has the natural setting as the direct source of data the researcher is the key instrument". Sedangkan menurut metodenya yaitu penelitian tindakan dengan jenis science action (emphasises the study of practice in organisational settings as a source of new understandings and improved practice) (Kemmis, McTaggart, \& Nixon, 2014). Objek penelitian dilaksanakan di Dinas Pendidikan Provinsi Jawa Timur dengan subjek kepala sekolah dan guru baik jenjang SD, SMP, dan SMA yang mengikuti pelatihan tentang program PPST. Metode pengumpulan data dengan menggunakan teknik wawancara, observasi, serta penilaian proses bagian team building (Tomal, 2010), dimana penilaian proses dilakukan dengan sekelompok subjek saling menukarkan ide, gagasan terkait pelaksanaan program PPST di sekolah sesuai dengen jenjeng pendidikan serta membuat rencana tindakan untuk perbaikan.

\section{HASIL DAN PEMBAHASAN}

\section{Pengembangan dan Peningkatan Seni Tradisional Jenjang SD, SMP dan SMA}

Mengapa PPST lahir? Ide ini muncul karena kebiasaan dalam melaksanakan seni tradisional di sekolah-sekolah yang tidak berkelanjutan. Beberapa hal yang dapat diamati akhir-akhir ini diantaranya, panggung yang ada di sekolah hanya untuk acara perpisahan sekolah, tetapi tidak disertai dengan pengembangan dan peningkatan seni tradisional yang berkelanjutan.

Dengan kewajiban untuk "membangun" kesenian tradisional lokal yang dibedakan antara PPST dan seni masyarakat lokal. Kemajuan pesat PPST harus selaras dengan pertumbuhan kesenian tradisional. Salah satu indikator keberhasilan adalah kerjasama yang saling menguntungkan dengan kelompok kesenian tradisional lokal sebagai wujud dari upaya untuk melestarikan seni tradisional itu sendiri. Sampai dengan tahun 2015 jumlah anggota PPST untuk jenjang SD / MI sebesar 35 lembaga, untuk SMP / MTs sebesar 52 
lembaga, sedangkan tingkat SMA / MA mencapai 42 lembaga.

\section{Pemimpin Transformasional sesuai Ki Hajar Dewantara}

Menggunakan pendekatan atau perspektif yang beragam tentang kepemimpinan, juga menghasilkan teori kepemimpinan yang beragam pula. Luthans (2011) mengidentifikasi dua jenis kepemimpinan, yaitu transaksional dan transformasional. Kepemimpinan transaksional meliputi pertukaran hubungan antara pemimpin dan pengikut, sedangkan kepemimpinan transformasional didasarkan pada pergeseran nilai dan keyakinan dari para pemimpin, serta kebutuhan para pengikutnya. Pemimpin transformasional memiliki visi, keahlian retorika dalam mengelola kesan yang baik dan menggunakannya untuk mengembangkan ikatan emosional yang kuat dengan para pengikutnya (Hanson, 2003). Pemimpin transformasional diyakini lebih berhasil dalam mendorong perubahan organisasi karena inspirasi pengikutnya dan kesediaannya untuk bekerja dalam mewujudkan visi pemimpin. Sementara itu, pemimpin transaksional tidak memiliki karakteristik seperti pemimpin transformasional yang mampu mengembangkan ikatan emosional yang kuat dengan atau menginspirasi pengikutnya untuk melakukan lebih dari yang mereka pikirkan.

Pemimpin transaksional diyakini dapat memotivasi pengikutnya dengan menetapkan tujuan dan janji-janji imbalan untuk kinerja yang baik. Hal ini relevan dengan hasil penelitian bahwa "the relationship between instructional leadership and the level of teachers' commitment is high. There is a significant relationship between instructional leadership and the level of teachers' commitment in three MJSCs in Pahang" (Ail, Taib, Jaafar, Salleh, \& Omar, 2015). Dimana dalam kepemimpinan instruksional secara efektif serta signifikan dapat mendorong komitmen guru sehingga pelaksanaan program peningkatan dan pengembangan seni tari tradisional dapat berjalan optimal.

Konsep kepemimpinan yang ideal tidak hanya dari teori yang hadir dari dunia barat semata. Ki Hajar Dewantara sebagai salah satu tokoh pendidikan nasional Indonesia mendefinisikan tiga konsep utama atau konsep ideal pemimpin. Dimana landasan kepemimpinan pendidikan di Indonesia terdiri dari tiga prinsip, yaitu:
1. Ing Ngarso Sung Tulodo

'Ingngarso' memiliki makna di depan atau di muka, 'Sung' berasal dari kata ingsun berarti saya, 'Tulodo' berarti panutan. Jadi seluruh makna Ing Ngarso Sung Tulodo menjadi seorang pemimpin harus mampu memberikan teladan bagi orang-orang disekitarnya. Jadi yang harus ditaati oleh seseorang dikatakan panutan. Prinsip ini menggambarkan situasi di mana seorang pemimpin bukan hanya sebagai orang yang berada di depan, tetapi juga harus menjadi contoh untuk orang-orang yang mengikutinya.

2. Ing Madyo Mbangun Karso

'Ingmadyo' berarti di tengah, 'Mbangun' berarti menghasilkan atau merangsang dan 'Karso' berarti kehendak atau niat. Jadi seluruh arti kata adalah seseorang di tengahtengah (lingkungannya) harus mampu meningkatkan atau merangsang semangat orang-orang yang berada di lingkungannya. Oleh karena itu seseorang juga harus memberikan inovasi dalam lingkungan mereka dengan menciptakan suasana yang lebih kondusif untuk keamanan dan kenyamanan. Prinsip ini sarat dengan makna kebersamaan, kerjasama tim, dan kerjasama sebagai seorang pemimpin harus selalu memberikan penyemangat kepada pengikutnya.

3. Tut Wuri Handayani

'Tut Wuri' berarti mengikuti dari belakang dan 'Handayani' cara memberikan dukungan moral atau dorongan. Jadi arti dari Tut Wuri Handayani adalah seorang pemimpin harus memberikan dorongan moral dan semangat dari belakang. Dukungan moral ini sangat dibutuhkan oleh orang-orang di sekitar kita dengan merangsang motivasi dan semangat. Saat prinsip ini menjadi slogan pendidikan Indonesia, yang tentunya memiliki makna yang mendalam. Jika diartikan tujuan Tut Wuri Handayani secara keseluruhan untuk membuat orang yang mandiri dan tidak bergantung pada orang lain dan diharapkan muncul generasi baru yang akan berani memimpin tanpa menunggu orang lain untuk memimpin.

\section{Peran Kepemimpin Kepala Sekolah terhadap Pengembangan dan Peningkatan Seni Tradisional}

Belajar seni dan budaya pada dasarnya terdiri dari dua metode dasar, yaitu belajar dengan melihat dan belajar dengan melakukan. Belajar seni dan budaya dengan melihat penekanan pada ketajaman visual. Artinya, bukti konkret harus muncul di muka 
sehingga mereka mengerti. Selain belajar dengan melihat dapat diartikan dengan membaca referensi terkait sehingga dapat meningkatkan wawasan dan pengetahuan di bidang seni dan budaya. Sementara belajar seni dan budaya dengan melakukan praktek langsung mampu untuk mengasah kemampuan seni. Dengan menerapkan kedua metode tersebut diharapkan akan maksimal dalam mengeksplorasi bakat seni.

Dari penjelasan di atas, dapat digambarkan sebagai berikut.

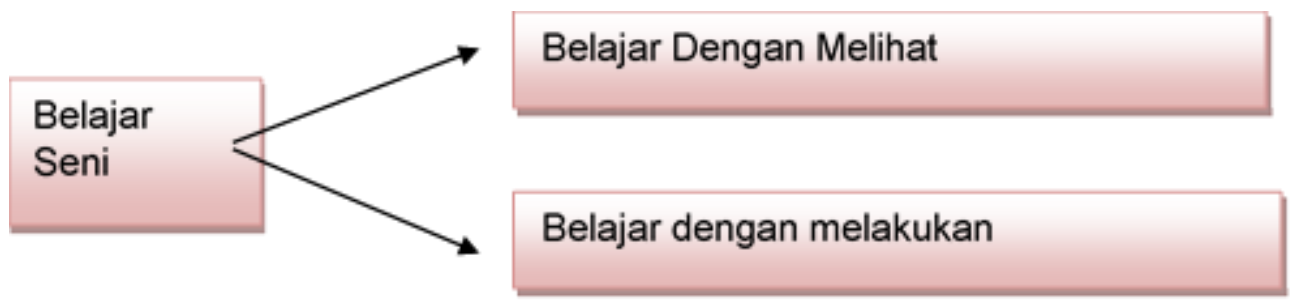

Gambar 1. Belajar Seni Tradisional

Dalam melaksanakan tugasnya untuk melaksanakan PPST, seorang guru yang telah ditunjuk sebagai PPST penasihat di lembaga sekolah akan membutuhkan dukungan, terutama dari para pemimpin. Peran kepala sekolah sebagai pemimpin lembaga sekolah akan menentukan keberhasilan program, serta prestasi sekolah termasuk kinerja guru. Kepala sekolah sebagai administrator di sekolah memegang peran yang sangat penting dalam mempengaruhi dan mengarahkan semua personil sekolah yang ada, untuk bekerja sama dalam mencapai tujuan organisasi sekolah. Sama pentingnya adalah produktivitas organisasi sekolah seperti yang terlihat pada efektivitas dan efisiensi pengelolaan serta kualitas dan kuantitas lulusan dan prestasi lainnya yang dicapai oleh sekolah.

PPST sebagai organisasi yang ada di lingkungan sekolah tidak terlepas dari peran kepala sekolah. Kepala sekolah serta pemimpin tertinggi dari para pembuat kebijakan diharapkan memiliki sikap kepemimpinan transformasional, yaitu: (Luthans, 2011)

1. Karismatik, kepala sekolah yang telah mempersiapkan visi dan misi, membawa rasa bangga dalam organisasi sekolah yang dipimpin.

2. Inspiratif, dimana kepala sekolah dapat mengungkapkan tujuan penting dengan cara yang sederhana dan mudah dipahami oleh anggota sekolah.

3. Stimulasi intelektual, yaitu kepemimpinan kepala sekolah dalam memecahkan masalah yang dihadapi oleh organisasi sekolah.
4. Perhatikan individu, yang menunjukkan perhatian terhadap setiap anggota sekolah.

Seorang kepala sekolah yang menerapkan konsep kepemimpinan transformasional diharapkan mampu menjalankan program PPST lebih hidup, utamanya pada kegiatan seni dan mampu mencapai prestasi di bidang seni tradisional. Kepala sekolah juga harus mampu memotivasi guru untuk melaksanakan program PPST guna mendorong guru untuk menerapkan seni budaya serta metode belajar dengan melihat dan melakukan untuk mengasah kemampuan dan wawasan di bidang kesenian tradisional bagi siswa.

Konsep kepemimpinan transformasional pada dasarnya sangat relevan dengan konsep kepemimpinan yang ideal seperti yang dikatakan oleh Ki Hajar Dewantara di atas. Seorang pemimpin dituntut untuk mampu menjadi contoh di depan anggotanya, meningkatkan moral dan motivasi di tengah anggotanya, serta mampu memberikan dukungan moral dan motivasi di balik anggotanya. Kepala sekolah harus mampu berada di posisi dan kondisi tanpa mengesampingkan posisinya sebagai pemimpin. Sebagai seorang pemimpin yang memiliki pengaruh, seorang kepala sekolah memiliki kewenangan dalam melaksanakan perintah yang perlu diikuti oleh orang-orang yang dipimpinnya. Dengan demikian seorang kepala sekolah bisa membuat perubahan dalam cara berpikir, sikap, perilaku dalam mengarahkan pengikutnya.

Sampai saat ini, masih ada hambatan atau kendala dalam pelaksanaan program PPST baik dialami oleh organisasi PPST yang bersangkutan atau pihak yang terlibat dalam implementasi PPST. Adapun hambatan atau kendala antara lain: 
1. Terbatasnya jumlah guru yang memiliki seni dan latar belakang pendidikan seni tradisional. Fakta terjadi di sekolahsekolah saat ini masih kekurangan guru seni yang memiliki kompetensi dan latar belakang seni. Kadang-kadang seni justru pelajaran yang diajarkan oleh guru mata pelajaran lainnya. Hal ini menyebabkan kurangnya pendidikan seni di sekolah tidak cukup baik karena guru tidak memahami materi yang diajarkan.



2. Kurangnya pemahaman PPST di sekolah. $\mathrm{Hal}$ ini disebabkan oleh perubahan pokok, sehingga kepala sekolah baru tidak mengerti atau tahu tentang program PPST.

3. Keterbatasan dana yang dialami oleh organisasi PPST di sekolah.

4. Dukungan dan perhatian dari instansi terkait tidak optimal.

Dari pemaparan di atas, dapat diperjelas dengan tampilan skema/ bagan di bawah ini.



Pemimpin yang ideal seperti yang dikatakan oleh Ki Hajar Dewantara

1) Ingarso Sun Tulodo

2) IngMadya Mangun Karsa

3) Tut Wuri Handayani

Gambar 2. Model Kerangka Pendidikan dan Pengembangan Seni Tradisional

Hasil penelitian tindakan ini dapat disimpulkan bahwa dalam menjamin terlaksananya program PPST di lembaga sekolah yang berkelanjutan dan berprestasi harus dikendalikan oleh seorang kepala sekolah. Kepala sekolah yang menerapkan konsep kepemimpinan transformasional dengan memegang teguh ajaran Ki Hajar Dewantara diharapkan dapat membuat pelaksanaan program PPST lebih hidup untuk kegiatan seni dan bisa mendapatkan prestasi di bidang seni

\section{SIMPULAN DAN SARAN}

Kesenian tradisional di Jawa Timur patut mendapat perhatian khusus mengingat sebagian besar mengalami stagnasi bahkan beberapa dianggap terancam. Kondisi ini disebabkan oleh pergeseran nilai-nilai dalam masyarakat yang mengakibatkan kesenian tradisional Jawa Timur kehilangan fungsinya sebagai warisan budaya yang harus dilestarikan dan dikembangkan. Untuk mengatasinya perlu inovatif bidang seni.

Kepala sekolah memainkan peran penting untuk memastikan organisasi di lembaga sekolah agar tetap lestari dan prestasi. Seorang kepala sekolah yang menerapkan kepemimpinan transformasional dan konsep kepemimpinan yang ideal Ki Hajar Dewantara diharapkan mampu membuat organisasi PPST lebih hidup utamanya pada kegiatan seni serta mampu berprestasi di bidang seni. 
Sebagai upaya melestarikan seni tradisional, terutama melalui pendidikan untuk program PPST di sekolah diharapkan:

1. Membuat seni dalam proses transformasi ilmu pengetahuan dan menyeimbangkan kegiatan akademik dan ekstrakurikuler seni tradisional.

2. Seni di sekolah sebagai bagian dari upaya untuk menciptakan manusia yang beretika dan berbudaya, sehingga dapat menjadi "tameng" terhadap budaya asing yang tidak sesuai dengan etika dan budaya bangsa.

3. Mengembangkan program studi seni tradisonal dalam bentuk mata pelajaran khusus.

4. Mengintegrasikan kegiatan seni dan budaya di kegiatan sekolah.

\section{DAFTAR PUSTAKA}

Ail, N. M. B. M., Taib, M. R. b., Jaafar, H. b., Salleh, W. A. R. b. M., \& Omar, M. N. b. (2015). Principals' Instructional Leadership And Teachers' Commitment In Three Mara Junior Science Colleges (Mjsc) In Pahang,
Malaysia. Procedia - Social and Behavioral Sciences, 191, 18481853.

Bogdan, R., \& Biklen, S. K. (1997). Qualitative Research for Education. Boston: Allyn \& Bacon.

Hanson, E. M. (2003). Educational Administration and Organizational Behavior : 5th Edition. Boston: Person Education, Inc.

Kemmis, S., McTaggart, R., \& Nixon, R. (2014). The Action Research Planner. Singapore: Springer.

Luthans, F. (2011). Organizational Behavior : 12th edition. New York: McGraw-Hill Companies, Inc.

Tomal, D. R. (, 2010). Action Research for Educators (Second Edition). Maryland: Rowman \& Littlefield Education.

Undang-Undang Republik Indonesia Nomor 20 Tahun 2003 Tentang Sistem Pendidikan Nasional 